Article

\title{
Constitutionalization and Entrepreneurship: Explaining Increased EU Steering of Renewables Support Schemes
}

\author{
Elin Lerum Boasson ${ }^{1,2}$ \\ ${ }^{1}$ Department of Political Science, University of Oslo, 0852 Oslo, Norway; E-Mail: e.I.boasson@stv.uio.no \\ ${ }^{2}$ CICERO-Center for International Climate Research, 0813 Oslo, Norway
}

Submitted: 29 November 2018 | Accepted: 4 February 2019 | Published: 28 March 2019

\begin{abstract}
This article sheds light on two under-researched issue areas: the energy policy-shaping role of the Court of Justice of the European Union (CJEU) and how constitutionalization of EU state aid law gives the European Commission (Commission) increased leverage over EU policy development. EU state aid governance is embedded in the Treaty of the Functioning of the EU's prohibition of state aid. The CJEU and the Commissions' Directorate-General for Competition (DG Comp) have played important roles in the emergence of stronger EU steering of renewable energy support schemes after 2014. For many years, powerful member states, most notably Germany, stopped the adoption of EU rules requiring more market streamlining and European harmonization of renewables support. This primarily played out in regular EU decision-making (co-decision) related to adoption and revision of the Renewable Energy Directive. A radical shift occurred in 2014 when the Commission introduced new guidelines on state aid for environmental protection and energy, giving the Commission increased authority over development of renewables support schemes across Europe. These guidelines called for renewables investments to become more exposed to energy market pricing and introduced auctioning as the main allocation mechanism. Support schemes for renewable energy were included for the first time in the EU state aid guidelines for environmental protection in 2001. Back then, member states had ample leeway to design support schemes as they pleased. The 2014 version of the guidelines includes far more detailed requirements. While the first CJEU ruling on renewables state aid hindered the Commission to intervene, new CJEU rulings after 2008 enabled the Commission to draft more restrictive guidelines. This article concludes that constitutionalization, combined with the policy entrepreneurship of Commission officials, explains the shift in EU steering in 2014. This indicates that constitutionalization and Commission entrepreneurship should be assessed in conjunction. Constitutionalization may be particularly important in the state aid area due to the superior competence of the Commission.
\end{abstract}

\section{Keywords}

constitutionalization; Court of Justice of the European Union; European Commission; judicialization; policy entrepreneurship; renewable energy policy; state aid

\section{Issue}

This article is part of the issue "EU Energy Policy: Towards a Clean Energy Transition?", edited by Kacper Szulecki and Dag Harald Claes (University of Oslo, Norway).

(C) 2019 by the author; licensee Cogitatio (Lisbon, Portugal). This article is licensed under a Creative Commons Attribution 4.0 International License (CC BY).

\section{Introduction}

Susanne K. Schmidt (2018) and Dieter Grimm (2015, 2017) argue that over time, the Treaty of the Functioning of the EU (hereinafter 'Treaty') ${ }^{1}$ has acquired the role of the EU's de facto constitution. Due to this development, case law from the Court of Justice of the European Union (hereinafter 'CJEU' or 'Court') ${ }^{2}$ has acquired constitutional status. This gives the Court more influence over EU policy development than many EU scholars rec-

\footnotetext{
${ }^{1}$ This Treaty has changed name several times over the years and the 2009 Lisbon Treaty introduced the term referred here. I will refer to it as 'the Treaty' irrespective of time period.

2 In 2009 the Treaty of Lisbon introduced the term 'Court of Justice of the European Union'. Formerly it had been named 'Court of Justice of the European Community', commonly referred to as the 'European Court of Justice' in the literature (see Saurugger \& Terpan, 2017, pp. 2-3).
} 
ognize. Schmidt (2018) finds that EU policymaking has become highly constrained by case law in the sense that the Council of the European Union (hereinafter 'Council') and the European Parliament (hereinafter 'Parliament') often adapt their decisions to harmonize with case law (Schmidt, 2018, p. 3). In this article, we explore how and to what extent constitutionalization may enable the European Commission (hereinafter 'Commission') to make important policy decisions on its own without ordinary democratic procedures.

State aid is an especially interesting issue area to explore when it comes to the relationship between CJEU case law and the Commission. Several authors argue that the Commission has increasingly used state aid rules as its last resort to steer national developments (Blauberger, 2009; Smith, 1998). EU state aid rules are inherently political; they involve choosing between competing political objectives, and the decision outcomes constrain the powers of national governments (Büthe, 2016, p. 38; Kassim \& Lyons, 2013). It is the prerogative of the college of Commissioners to adopt state aid guidelines (Büthe, 2016; Commission, 2014). Such guidelines must draw on the Treaty and CJEU case law, and must present principles for assessment of compatibility of aid (Banet, in press). The guidelines are not legally binding on member states, but they are binding on the Commission. Member states may challenge the guidelines, but this may entail long delays and hold back renewables investments while litigation goes on. Hence, the exact wording of the state aid guidelines may be of crucial importance for development of national practices in the areas they cover. Still, few scientists have attempted to explain revisions of EU state aid guidelines (for one of the exceptions, see Flåm, 2009).

This article presents a longitudinal study of how CJEU case law has influenced EU renewables policy development from the 1970s up to 2014. It pays particular attention to how constitutionalization has constrained and enabled the Commission to perform entrepreneurship and thus 'induce authoritative political decisions that would not otherwise occur' (Moravcsik, 1999, p. 271). Until quite recently, feed-in schemes dominated in the EU. These offered beneficiaries a fixed price for electricity for 15 to 20 years, independent of market price fluctations, often ensuring different renewables technologies different levels of support (Cointe \& Nadaï, 2018). To the surprise of many, the 2014 state aid guidelines steered the countries towards shifting to competitive auctioning combined with feed-in premium (a support on top of the spot market electricity price; Fitch-Roy, Benson, \& Woodman, 2019).

Hence, this article asks: How and to what extent have constitutionalization and Commission entrepreneurship shaped the 2014 shift in EU steering of national renewables support schemes?

While EU renewables policy development follows ordinary legislative procedure (formerly called co- decision), the Commission has the upper hand in revising state aid guidelines. In the ordinary procedure, the Commission presents a draft, the Council and the Parliament put forward amendments and, finally, the Parliament and the Council jointly adopt a decision. The Commission's Directorate-General for Energy (DG Ener) drafts renewables policy proposals, while the DirectorateGeneral for Competition (DG Comp) drafts state aid guidelines ${ }^{3}$. Governance scholars have recently stepped up their efforts to make sense of the radical expansion of renewable energy within the EU. Hence, we now know far more about the politics and dynamics of EU renewables policy than a few years back (e.g., Boasson \& Wettestad, 2013; Bürgin, 2015; Cointe \& Nadaï, 2018; Solorio \& Jörgens, 2017). However, we still lack a good understanding of the 2014 shift towards stronger EU steering of national support schemes. This shift did not result from changes in the EU renewables policy proper, but rather from the introduction of new guidelines on state aid for environmental protection and energy. Some authors have explored how the 2014 shift in the EU state aid steering influenced renewable energy decisionmaking at the member state level, but this article is the first (to my knowledge) that aims to explain the 2014 shift (Leiren \& Reimer, 2018; Tews, 2015).

As a general rule, the Treaty prohibits state aid, and the state aid guidelines are intended to help clarify when renewables support qualifies as state aid and under which conditions it can still be accepted (Banet, in press). The state aid guidelines clarify these conditions. In order to fall under the Treaty's definition of state aid, renewables aid must be: 1) granted by a member state or through state resources; 2) distort or threaten to distort competition; 3 ) selectively favour certain undertakings; and 4) affect trade between member states (Community Guidelines, 2008, Article 7.1). Renewables aid that fulfils these criteria can only be accepted if it promotes EU climate and energy policy objectives and interests (Community Guidelines, Article 1).

The 2014 guidelines differ radically from how renewables support was dealth with in prior guidelines and renewables directives. They prescribe that aid be 'granted in a competitive bidding process on the basis of clear, transparent and non-discriminatory criteria' (Community Guidelines, Article 3.3.2.). Indeed, all new aid schemes are required to grant aid as a premium in addition to the electricity market price. The bidding process may be limited to specific technologies if certain conditions are met: if there is a 'need to achieve diversification'; if the installed electricity capacity is very small; if the number of projects is limited; or if competitive bidding could lead to higher support levels. Such exemptions may only be made if they do not distort the electricity market or if the energy markets are so poorly designed that market-based support schemes would not work. The Commission argues that during 2020-2030 established renewable energy sources will become grid-

\footnotetext{
${ }^{3}$ The names of these DGs vary during the period covered by this paper. For simplicity I will refer to them consistently as 'DG Comp' and 'DG Ener'.
} 
competitive and subsidies should be phased out in a degressive way (Community Guidelines, 2014 Article 3.2.4). The 2014 guidelines accept electricity certificate markets (also called renewables portfolio standards) as an alternative to auctioning and feed-in premium.

We will now discuss how constitutionalization and Commission entrepreneurship may help us assess and understand this outcome.

\section{Constitutionalization and Commission Entrepreneurship}

In the early 1960s, the CJEU declared EU law 'to be directly applicable in the Member States to the effect that individuals could derive rights from it and claim them before the national courts' and decided that the Treaty should enjoying 'primacy over national law' (Grimm, 2015 p. 466; see also Schmidt, 2018, p. 1). Based on this jurisprudence the Treaty started to serve as a constitution: when the treaties are applied in accordance with the binding interpretations of the CJEU, European integration that is not endorsed by the member states may occur (Grimm, 2015, p. 469, 2017, p. 5).

The CJEU has influenced the behaviour of EU policymakers, which in turn has influenced EU policy on many issues (Martinsen, 2015, p. 1622; Saurugger \& Terpan, 2017, p. 3; Stone Sweet, 2010, p. 7). For many years, scholars understood this development as 'judicial activism' or 'judicialization', referring 'to a process through which judges and courts act as policymakers, complementing, substituting or competing with political actors' (Terpan \& Saurugger, 2018, p. 1). This research tradition primarily explores the CJEU judges' motivations and rulings. In contrast, the emerging 'constitutionalization' literature aims at increasing our understanding of how the CJEU influences European integration and EU policy development in the long run (Grimm, 2015; Schmidt, 2018; Weiler, 1991).

Because EU politics is 'too fragmented to respond to and correct the court', the CJEU judges have ample opportunity to influence EU policy development (Grimm, 2019, p. 9; Martinsen, 2015, p. 12). Susanne K. Schmidt (2018, pp. 3, 8-9) argues that ambiguous and unclear formulations in the Treaty and in EU secondary law (such as directives and regulations) generate legal uncertainty. This leads private actors to litigate issues for the Court, resulting in rulings that again advance the impact of EU law. To create more legal certainty, EU policymakers may subsequently codify CJEU case law into secondary EU law (by, for example, incorporating them into directives or regulations). In issue areas characterized by constitutionalization, the leeway that member states have 'ultimately depends on the extent to which the Court rules that the Treaty applies to the national situation' (Schmidt, 2018, pp. 10-11).

Schmidt (2018, p. 7) argues that constitutionalization will play out in path-dependent ways and over long periods. The constitutional nature of case law, policymak- ers' inherent tendency to develop ambiguous compromises, and the CJEU's tradition of responding to all cases that are brought before it will eventually create a pathdependent development whereby CJEU's rulings will end up determining policy development in certain areas. The initial rulings will be particularly important.

Based on this background, we expect to find that the 2014 shift in the EU steering of national renewables support schemes can be explained by:

- Neither the EU Treaty nor the EU renewables policy proper providing legal certainty about renewables support schemes, causing the CJEU to be challenged to resolve the issue.

- Initial CJEU rulings on national renewables support schemes creating precedence for later decisions, leading to a gradual case law development that eventually brought about the 2014 shift.

In this article, we are particularly interested in exploring whether and how constitutionalization within the state aid area may strengthen the ability of the Commission to perform successful entrepreneurship. While Schmidt underlines that the Commission has a key role due to its privileged access to and knowledge about the Court, she concludes that we know little about how the Commission may exploit the constitutionalization logic to strengthen its impact (Schmidt, 2018 p. 35). On the other hand, several studies of EU state aid policy (Blauberger, 2009; Smith, 1998) conclude that the Commission has enhanced its autonomy in state aid cases by repeatedly performing entrepreneurship, exploiting CJEU rulings to gain progressively more power over this issue area.

Policy entrepreneurship 'is an effort to wield political power' and to 'induce authoritative political decisions that would not otherwise occur.' (Moravcsik, 1999, p. 271). It is performed by actors who seek to 'punch above [their] weight' (Green, 2017, p. 1473). By contrast, actors who merely 'do their job' and do what is 'appropriate' cannot be considered entrepreneurs (Boasson \& Huitema, 2017, p. 1351). Commission officials can perform different types of entrepreneurship. First, they may perform cultural-institutional entrepreneurship, in the sense that they consciously frame their ideas and proposals to make them appear as attractive as possible (Boasson, 2015, p. 68). If this is the case, we will see that Commission officials have actively framed their favoured support scheme designs as superior, and have worked methodically to ensure that these understandings be included in the state aid guidelines.

In addition, the Commission may perform structural entrepreneurship; that is, acts aimed at enhancing influence by altering the distribution of authority and information (see Boasson, 2015, p. 70). Networking and the strategic use of decision-making procedures are particularly important in this respect. Concerning the former, we expect Commission officials to have had much informal contact with Commission officials in 
other directorates-general as well as with key societal actors such as electricity utilities and renewables industry actors. Commission officials will use these networks to persuade others and ensure coordinated behaviour (Fligstein \& McAdam, 2012).

When it comes to the strategic use of decisionmaking procedures, Commission officials will aim to exploit open policy windows and perform venue shopping. Exploitation of policy windows relates to timing: the ability to launch a proposal at the exact moment in time when it is most likely to be adopted. Kingdon (1984/2011, p. 165) regarded a policy window as 'an opportunity for advocates of proposals to push their pet solutions, or to push attention to their special problems.' Subsequent studies have shown that the existence of policy windows enhances entrepreneurial activities and sometimes also entrepreneurial success (see review in Boasson \& Hutema, 2017, p. 1354). Entrepreneurs can also enhance their influence by ensuring that their 'pet issue' comes up for decision in the decision-making venue where it is expected to achieve their preferred outcome. For instance, we expect Commission officials to strategically assess whether their favoured solutions are more likely to be accepted in the revision of state aid guidelines or in the revision of the EU renewables policy proper (Kingdon, 1984/2011).

On this background, we expect to find that the 2014 shift in the EU steering of national renewables support schemes can be explained by:

- Commission officials working strategically to frame feed-in premiums combined with auctioning as the most appropriate support scheme design.

- Commission officials exploiting policy windows as well as performing venue shopping and networking to achieve their preferred outcome.

Let us now move on to present the longitudinal qualitative case study. The main method is process tracing; systematic within-case analysis aimed at identifying associations between cause and outcome. Four main sources have been combined: 1 ) reviews of existing literature on EU renewables and state aid policies (political science as well as juridical literature). Existing literature, including my own study of EU renewables directives, has been especially important for descriptions of the oldest phases of development; 2) systematic assessments of Commission working documents, state aid guidelines from 2001, 2008 and 2014, inputs to two public consultation processes between 2012 and 2014, and relevant Court judgements and advocate general opinions; 3) semi-structured interviews with 10 individuals from DG Comp, DG Ener and DG Legal Service (cabinet members as well as lower-ranking civil servants) and representatives from electricity and renewables energy industry associations. Due to the sensitive nature of the issue, all interviewees are anonymized and no interviews were recorded. All interviews where transcribed imme- diately after being conducted (see list of interviewees). Interview information has primarily been used to specify details in the chronological order and to specify relationships between various actors. Information from the different interviewees has been systematically compared.

\section{Renewables Support: From Rare and National to Common and EU Steered}

\subsection{0-1999: The Commission Promotes an EU-Wide Market-Based Scheme and Challenges German Feed-In}

During most of this period, the EU's authority within the realm of state aid was contested, and renewable energy was primarily a national policy issue (Boasson \& Wettestad, 2013; Büthe, 2016, p. 39). After the oil shocks in the early 1970s, three different domestic renewables strategies gradually emerged. First, Germany, Denmark and, eventually, Spain embarked on technology-specific schemes, with no exposure to market forces (Boasson \& Wettestad, 2013, pp. 82-83). They launched feedin schemes, relying on fixed support levels for rather long time periods and guaranteed grid access. These schemes led to the emergence of small-scale domestic renewable energy industries. The second group of countries-Finland, the Netherlands, Sweden and the UK-offered R\&D support and some other measures, but did not develop feed-in schemes. In these countries, the traditional utilities initiated a few renewable energy plants but no new renewables industries emerged. The third and largest group of European countries hardly promoted renewables.

In 1988 the Commission considered harmonizing renewables support, but this came to nothing (Rusche, 2015 , p. 25 , p. $81-82$ ). The first renewables schemes were notified to the Commission in 1990; DG Comp found that both the British and the German schemes constituted state aid, but swiftly approved both. A little later, DG Comp endorsed schemes in the Netherlands, Sweden, Finland and Denmark.

Germany subsequently changed its scheme and the German Utilities Association lodged a complaint with the Commission over application of the state aid rules (Jacobsson \& Lauber, 2006). In response, DG Comp sent a letter to the German government expressing doubt about the continued compatibility with state aid rules and proposing amendments that would bring German law in line with the rules, leading to a reduction in feedin rates (CJEU, 2000, Articles 19-21). In 1998 Germany introduced a revised scheme but, despite consultations with DG Comp, did not follow up any of the proposals from the Commission (CJEU, 2000, Articles 34-38). Instead, Germnay decided that the distribution system operators (DSOs) could pass on their additional economic burden from buying electricity from renewables to the transmission system operators (TSOs). Although CG Comp complained about this to Germany, it refrained from asking Germany to notify because it expected a 
new renewables directive to introduce harmonised renewables rules.

At this stage, the electricity supplier PreussenElektra AG refused to pay Schleswag (distribution system operator) the extra costs incurred in buying renewables electricity required by the German feed-in law (Kuhn, 2001; Rusche, 2015, p. 38). The issue was brought before a German court, which eventually asked the CJEU to clarify whether PreussenElektra was right when it argued that the German scheme fell under the Treaty's definition of state aid (CJEU, 2000, 2001). In the two years that passed before the CJEU reached a judgement, a major political controversy emerged in Brussels over EU steering of renewables aid in a new renewables directive (CJEU, 2000, Article 38).

DG Ener argued that national support schemes were no longer compatible with state aid rules. It suggested creating a market-based pan-European 'renewable energy credit' scheme, and began drafting a directive that would lead to this development (Boasson \& Wettestad, 2013, pp. 84, 87; Rusche, 2015, p. 30). While the largest European electricity utilities supported the idea, the renewable energy industry mobilized against it (Boasson \& Wettestad, 2013, pp. 84-85). Both industries had ties to Commission officials who supported their opposing views.

While the German government protested vigorously against the Commission's initiative, the Netherlands, Sweden and the UK were more positive. At the domestic level, the market idea got off to a rather bad start; the British quota system failed to yield much production and the Dutch government abandoned its voluntary certificate scheme soon after its introduction (Boasson \& Wettestad, 2013, pp. 85-86). In the end, the EU energy ministers allowed the Commission to develop a renewables directive on the condition that it did not aim to steer the national support schemes. In parallel, DG Comp began more actively reviewing member states' state aid practices in a range of issue areas (Büthe, 2016, pp. 56-58).

By the late 1990s the Court had largely confirmed that the Treaty gave the Commission substantial authority over state aid, but it was unclear which and how many renewables schemes fell under the Treaty's definition of state aid (Büthe, 2016, pp. 56-58). The Commission had gained authority to require recipients of unlawful aid to repay aid, but many years would pass before it became clear whether it could apply this authority to renewables schemes.

\subsection{0-2004: The CJEU Constrains Commission Steering and Member States Block Harmonization}

The Commissions' understanding of how and to what extent it could influence national renewables support was fundamentally challenged during this period. In the midst of the heated discussion about the renewables directive, the advocate general of the CJEU in 2000 con- cluded that the changes that Germany had introduced to its feed-in law in 1998 were not sufficient to trigger the need for a new notification and, most importantly, that the scheme did not constitute state aid (CJEU, 2000, Article 19; Kuhn, 2001). Since neither PreussenElektra nor Schleswag was publicly owned, the money never actually passed through the state or through state resources, and thus the CJEU did not regard the German scheme as state aid (Rusche, 2015, p. 83). This decision came as a great surprise to DG Ener, DG Comp and DG Legal Service (the latter defended the view of the Commission in court; Interviewees 5, 6 and 8).

Already before the CJEU had made its decision, Germany changed its system again, introducing technologyspecific support levels guaranteed for 20 years (CJEU, 2000, Articles 34-38; Cointe \& Nadaï, 2018, pp. 6, $61)$. Gemany did not notify the revised scheme to the Commission, nor did France when it adopted a similar scheme, although the French government repaid utilities with state resources (CJEU, 2013; Rusche, 2015).

Many struggled to interpret the precedence created by PreussenElektra: did the ruling imply that neither the Commission nor the CJEU could overrule national renewables support schemes, or was the German case so special that it did not really create precedence (see Kuhn, 2001, p. 364; Rusche, 2015, p. 85)? Interviewees with knowledge of this period, regard PreussenElektra as highly significant. One (Interviewee 6) states: 'It is amazing how much this influenced the understanding of state aid.' DG Comp officials were confused, leading their decisions in the immediate aftermath of the judgment to lack consistency (Rushe, 2015, p. 86). In any event, the Court's decision legitimized a swift diffusion of feed-in schemes among EU member states (Cointe \& Nadaï, 2018, p. 63).

In 2000, DG Ener published a draft renewables directive, suggesting a deadline for EU wide harmonization of support schemes. The Parliament rejected the deadline, and eventually the Energy Council accepted the draft with notable exemptions. The renewable directive adopted in September 2001 made no reference to market streamlining or harmonization (European Parliament and Council 2001/77/EC). The same year, DG Comp launched the first state aid guidelines that included renewable energy. The guidelines did not promote market streamlining or harmonization (Community Guidelines, 2001). They distinguished between how investment support and operational support could be calculated, but introduced no clear limitations on how much a renewables plant could receive over its lifetime. Calculations of investment support should be based on the 'extra costs' compared to conventional plants. It was made clear that operating aid would 'usually be allowable' and two design options were presented: a) the 'extra cost' approach: provide aid 'to compensate for the difference between the production cost of renewable energy and the market price' or b) the application of 'market mechanisms such as green certificates or tenders' (Community Guidelines, Articles E.3.3.2 and E.3.3.3.). 
In the following years, the countries that first adopted feed-in schemes stayed on their original path and many others copied them, making feed-in the most common way to promote renewables (Boasson \& Wettestad, 2013, pp. 86-87). A few countries opted for green certificate schemes; for instance, Sweden adopted a scheme that immediately boosted renewables investment. Still, by 2005 the scientific literature as well as most DG Ener documents concluded that feed-in schemes were more effective and less costly than electricity (green) certificates (Cointe \& Nadaï, 2018, p. 72).

\subsection{5-2009: Conflicts over the Revised Renewables Directive, Little Attention Paid to Key CJEU Ruling}

When climate change climbed to the top of the EU agenda as the union prepared for the global climate summit in Copenhagen in 2009, conflicts over renewables support resurfaced (Boasson \& Wettestad, 2013, pp. 87-94). By now, a significant renewables industry had emerged that had exceptionally strong ties to parts of DG Ener and the Parliament. The renewables promoters were united in their skepticism towards market streamlining and EU harmonization.

By this stage, only seven EU member states had green certificate schemes, whereas 18 had feed-in schemes (Commission, 2008a). While many in DG Ener were pleased with the diffusion of feed-in schemes, other Commission officials started to float the idea of a panEuropean certificate scheme (Boasson \& Wettestad, 2013, pp. 87-94). They envisaged a scheme where aid would be granted to the least costly renewables projects, market forces would determine the support levels, and governments would no longer be able to favour specific technologies. The renewables industry, as well as German and Spanish ministries, criticized the idea. The tone of the discussion was harsh; actors accused each other of fraud, lack of credibility and of being reactionary.

DG Ener officials opposed to the market approach ensured that the draft directive was 'leaked' in December 2007 (Boasson \& Wettestad, 2013, p. 91). This happened only weeks before the Commission was to launch the draft. Even though the renewables community had little time to lobby against the draft, it largely succeeded. One month later, in January, the Commission issued a new and rather inconsistent draft directive, opening up for certificate trading but not for creating a pan-European scheme (Commission, 2008b). At the same time, DG Comp launched revised state aid guidelines. The 2008 guidelines were quite similar to the 2001 version and were not aligned with the draft directive. They did, however, give more weight to incentivizing lower support levels (Community Guidelines, 2008, Article 1.3.5). An interviewee (5) from DG Ener thinks that the state aid revision was not strongly coordinated with the renewables directive revision, while an interviewee from DG Legal Service (5) states: 'When they suggested developing a directive at the same time, it would be too blatant if they simulta- neously included it in the guidelines. This was due to political considerations.' A DG Comp interviewee states 'nobody cared about state aid guidelines in 2008. It is only more recently that it has attracted a lot of interest.'

At around the same time, the Court radically changed its interpretation of the Treaty. First, the CJEU advocate general issued an opinion in January 2008 in the Essent Netwerk Noord BV case, which dealt with state aid in the electricity sector in general. Here, the advocate general argued that PreussenElektra was very special; in this case the feed-in costs were not transferred through state resources, and no public entities or private entities created by the government were involved, but this was rare. Hence, it had little general value for how state aid rules should be understood (CJEU, 2008; Rusche, 2015, pp. 103-104). The Court upheld this view in July (Mortensen, 2008). According to interviewees $(5,6)$, DG Comp had long wanted to challenge PreussenElektra, and the Essent Netwerk Noord BV paved the way for such efforts.

The renewables directive revision was hotly debated throughout 2008. By now, an increasing number of voices raised the concern that many feed-in schemes overcompensated renewables (Cointe \& Nadaï, 2018, p. 90). A Commission interviewee (8) even states: 'We had a lot of people we had never seen before coming to us in black limousines. We understood back then that something was wrong.' This did not influence the political deliberations. A joint compromise proposal from the UK, Poland and Germany in June 2008 was a major breakthrough for the strategy of the renewables actors (Boasson \& Wettestad, 2013, p. 92). The proposal ensured member states control over their national support schemes. In the end, the Council and the Parliament adopted a directive that required member states to continue to offer state aid to renewables, but they did not give the Commission new authority.

By the end of 2009, the EU had adopted a directive that contained binding national renewables targets, but no constraints on national renewables support designs. A new CJEU ruling enabled the DG Comp to start applying its state aid powers on renewables support, but it seems like few actors noticed this significant shift in CJEU case law.

\subsection{0-2016: DG COMP Rises to the Occasion}

By 2010 it became clear that the economic crisis constrained many member states' ability to offer renewables support, while the renewables costs had reduced dramatically. This made many reconsider their views on renewables support schemes (Cointe \& Nadaï, 2018, pp. 89-90). Hence, the debate shifted from a trench war to a more nuanced, though still sometimes heated, exchange of knowledge and ideas (Cointe \& Nadaï, 2018, pp. 94, 945).

Introduction of a significant share of intermittent renewables changed the price-setting mechanisms in Eu- 
ropean electricity markets, largely to the disadvantage of the large utilities. Around 2012 it became clear that the industry faced severe economic challenges. The situation was particularly dire in Germany, where the wholesale power price was reduced by more than 50 per cent from 2011 to 2016 (Newbery, Pollitt, Ritz, \& Strielkowski, 2017, pp. 7-8). Over the years, Germany had added several compensation mechanisms to its support scheme, rendering the PreussenElektra ruling outdated. Hence, the German Association of Energy Consumers lodged a complaint with the Commission, arguing that the scheme constituted state aid (CJEU, 2016). In parallel, the CJEU considered whether the French feed-in scheme constituted state aid, and in 2013 ruled that it did (CJEU, 2013). This signified a shift in case law, and late in 2013 DG Comp initiated a formal investigation procedure with respect to the German scheme (CJEU, 2016, p. 13).

By this stage, DG Comp was in the midst of a major 'modernization' of all state aid practices, aimed at ensuring economic efficiency as well as legal certainty (FitchRoy et al., 2019). It asked stakeholders to complete a questionnaire concerning revision of the state aid guidelines relating to renewables. In their replies to this questionnaire, the renewables industry called for minor alterations to ensure a more effective implementation of the 2009 renewables directive, while the electricity industry largely said it was fine with existing practices (Commission, 2016). Assessment of the inputs indicate that few expected major changes in the new guidelines. However, as one interviewee states: 'The member states had committed to the [renewables] targets, but it had consequences that few had expected. When the financial crisis came in addition, it was like a perfect storm.' (Interviewee 4). DG Comp exploited this situation, and in 2013 it issued draft guidelines for consultation which suggested radically ramping up EU steering towards competitive tendering combined with feed-in premiums. One Commission interviewee (8) who used to promoted certificate schemes stated: 'We lost that in 2008 .... I was okay with tendering. It was simply another way to ensure competition and cost-efficiency'. Another (3) highlights how auctioning fits the thinking of the Commission in general and that the possibility for bidding processes had opened up in many areas of state aid.

As very few EU countries applied feed-in premium combined with competitive auctions at this stage, the Commission's proposal came as a great surprise, and aroused significant protests (Fitch-Roy et al., 2019). Note that while new CJEU rulings enabled the Commission to develop this proposal, the CJEU said little about how support schemes should be designed; it merely specified that most schemes constituted state aid. The draft received considerable attention and many inputs. The seven largest utilities and the business association Eurelectric supported the new approach (Commission, 2016). The renewables industry was more critical, arguing that the proposal conflicted with the renewables di- rective. Many interviewees, however, argue that the conflict over more or less market steering was not as prominent as before. DG Comp hailed the new UK and Dutch schemes as good models for national support schemes (Interviews; Commission, 2014).

Many member states, however, voiced skepticism. For instance, France, Germany, Poland, Sweden and the UK all argued that the proposal was too restrictive and called for more leeway. An interviewee that participated in consultation meetings ( 3 ) refer to considerable member state resistance. A letter from France, Germany, the UK, and Italy in December 2013 confirms this (Change Partnership, 2014). The member states wanted leeway to continue with technology-specific feed-in to the extent they saw fit, and to avoid having to open up their schemes to other countries. The final 2014 guidelines were quite similar to the draft proposal, but included significant exemptions from the feed-in premium and auctioning requirement, allowing for more widespread use of technology-specific feed-in than the 2013 proposal (Community Guidelines, 2014; see Tews, 2015, p. 276).

Germany changed its scheme towards feed-in premiums combined with auctioning already before the Commission concluded in 2014 that the scheme constituted state aid (CJEU, 2016, p. 16) ${ }^{4}$. One interviewee (6) argues that Germany would never have adjusted its scheme had it not been for Commission pressure, describing the meetings between DG Competition and Germany as 'really heated, really harsh' and 'they did all they could in this case'. Another interviewee (5) expresses doubt as to whether the German government was really that unhappy with the changes, commenting that 'the revision was in a way modelled on the German situation.'

Interviewees $(2,6,8$ and 9) indicate considerable disagreements between the DGs over the new approach, and internal coordination seems to have been limited. Nonetheless, the college of Commissioners adopted the guidelines in April 2014. According to several interviewees, the Commissioners cast formal votes, which is a rare event. Let us now turn to assess how and to what extent constitutionalization and Commission entrepreneurship shaped the 2014 shift.

\section{Assessment and Conclusions}

The new 2014 guidelines increased the Commission's steering of national renewable energy schemes, even though the guidelines are not binding on member states in strictly judicial terms. The guidelines asked the member states to adopt a support scheme design that was not widely used in the EU at the time. It does not seem likely that the member states would have endorsed this shift in the strength and direction of EU steering if it had been up for decision in an ordinary legislative procedure.

Let us first discuss how and to what extent constitutionalization contributed to this development. First, do we find that neither the EU Treaty nor the EU renew-

\footnotetext{
${ }^{4}$ The CJEU confirmed this decision in 2016 (CJEU, 2016).
} 
ables policy proper produced legal certainty about renewables support schemes, and because of this the CJEU was repeatedly challenged to resolve the issue? Yes, we do. This first happened with PreussenElektra, 10 years after the first schemes gained Commission endorsement. The CJEU took on the case because a German court had referred it, but the original court case was initiated by German electricity actors. This ruling had the opposite effect of what the German electricity industry had hoped for: it constrained, rather than enabled, the Commission to steer national support scheme development. Not until 2008 did the CJEU reach a decision that undermined PreussenElektra.

Second, did the initial CJEU ruling, PreussenElektra, create precedence for later decisions, leading to a gradual case law development that eventually brought about the 2014 shift? In one respect, we will have to answer in the negative; for a long time PreussenElektra hindered the Commission in interfering in national renewables scheme development. In contrast to the constitutionalization expectation, this ruling neither inspired EU renewable energy proper, nor was it challenged by this secondary legislation. However, the CJEU's Essent Netwerk Noord BV ruling in 2008 did opened up for pathdependent developments more in line with constitutionalization arguments. This judgement created precedence, and after this we see case law development that eventually contributed to the 2014 shift. This illustrates that CJEU rulings that undermine Commission steering are less likely to cause path dependence, primarily because such rulings hinder the Commission in making decisions that can be contested and in turn lead to new CJEU rulings. First when the CJEU breaks with a decision that constrains the Commission that pathdependent developments can be triggered. However, we will need to bring in Commission entrepreneurship to understand why the shift occurred in 2014 and why the Commission choose to favour feed-in premium combined with auctioning.

First, did Commission officials work strategically over time to frame feed-in premiums combined with auctioning as the most appropriate support scheme design? If we go back further than 2012, we need to reject this expectation. For several decades, DG Comp as well as officials from other DGs promoted a pan-European electricity (green) certificate scheme. The Commission first started to promote competitive bidding in combination with feed-in premiums in 2012. This was an adjustment to the political realities; after all, this design option was less different from the dominant feed-in scheme than a pan-European certificate scheme. Moreover, we have identified significant disagreements within the Commission, with centrally placed officials continuously defending the national feed-in approach. First during 2012 and 2013, DG Comp officials began to actively frame auctioning combined with feed-in premium as superior.

Second, did Commission officials exploit policy windows, and perform venue shopping as well as network- ing in order to achieve their preferred outcome? From the mid 1990s onwards, the Commission did try to exploit some policy windows, but performed little venue shopping and networking. From 2008 onwards, however, we can largely confirm this expectation. DG Comp officials skillfully exploited the policy window that opened around 2012. This window was created by the juxtaposition of the financial crisis, reduced technology prices, unforeseen electricity market distortions caused by increasing renewables shares, the electricity industry's mounting economic challenges and the initiation of the modernization process for of all types of EU state aid. As the debate over renewables support had become less riproaring and the ideological differences had lost importance, it also became easier for the college of Commissioners to endorse the shift.

Moreover, while Commission officials in 2008/2009 experienced that its draft renewables directive was completely rewritten by member states, DG Comp officials operated in a venue where the college of Commissioners rather than the member states had formal powers. This shift of venue did not result from a planned strategic move by a unified group of Commission officials from different DGs. Rather, we see that DG Ener and DG Comp officials primarily tried to influence the processes they led, i.e., where they held strong formal positions. As DG Comp had more authority to steer the state aid guidelines revision than what DG Ener had to steer the renewables directive revision, it is maybe not surprising that DG Comp was much more successful. The DG Ener officials who initially promoted a pan-European certificate scheme remained rather passive in the state aid guidelines revision. Indeed, we do not identify much contact between DG Comp and DG Ener officials. True, the electricity utilities and renewables industry had each developed contact with different officials in the Commission, but it does not seem as if either of these networks were important in the state aid guidelines revision process. Rather, as late as 2012 both groups seem largely unaware of the intentions of DG Comp. Entrepreneurship from DG Comp officials was crucial to the 2014 shift, but these actors came rather late to the game and do not appear to have collaborated much with actors outside the Commission. Hence, the expectation is confirmed with respect to policy windows, only partly confirmed with respect to venue shopping and largely refuted with respect to networking; the latter was not important.

We can conclude that the constitutionalization perspective increases our understanding of the 2014 outcome; CJEU case law development eventually enabled the Commission to steer through state aid guidelines, and hence constitutionalization contributed to withdrawing policy options from 'majoritarian decision-making at the European and national levels' (Schmidt, 2018, p. 2). Indeed, we find that the leeway available to member states ultimately depended on the extent to which the Court ruled that the Treaty applied to the national support schemes (Schmidt, 2018, pp. 10-11). The important 
shift in EU steering did not result from decision-making relating to EU's renewables policy proper, but was related to the Commission's drafting of state aid guidelines, a process where the Commission had the upper hand. However, this did not happen due to slow-moving irreversible path-dependent developments, as Susanne Schmit (2018) suggests. Rather, the entrepreneurship of Commission officials was crucial. Had it not been for the skilled exploitation of a policy window and the shift of decision-making venue, the Court's rulings would probably not have had that significant ramifications. The case presented in this article also indicates that constitutionalization may be more important than the literature on EU state aid policy suggests (Blauerger, 2009; Büthe, 2016). The 2008 CJEU ruling created a necessary basis for the shift, but the outcome would probably have been different if DG Comp officials, and eventually the college of Commissioners, had not risen to the occasion in the period 2012-2014. Note that the 2014 guidelines contain some exemptions to the main rules regarding feed-in premiums and auctioning. These seem largely to result from member state and renewables industry pressures and not from the factors highlighted in this article.

This article indicates that it is important to assess constitutionalization and Commission entrepreneurship in conjunction, and that constitutionalization may be particularly important in the state aid area due to the superior competence of the Commission.

\section{Acknowledgments}

Thanks to Catherine Banet, Åse Gornitzka, Merethe Dotterud Leiren, Sebastian Oberthür, Jon Birger Skjærseth, Jørgen Wettestad and two anonymous reviewers for valuable feedback to earlier drafts. The Research Council of Norway and other partners to the REMIX research project (project no. 243756) have contributed to financing the research.

\section{Conflict of Interests}

The author declares no conflict of interests.

\section{References}

Banet, C. (in press). Legal status and legal effects of the Commission's state aid guidelines. The case of the guidelines on state aid for environmental protection and energy (EEAG) (2014-2020). European State Aid Law Quarterly, 19(1).

Blauberger, M. (2009). Of 'good' and 'bad' subsidies: European state aid control through soft and hard law. West European Politics, 32(4), 719-737.

Boasson, E. L. (2015). National climate policy: A multifield approach. London: Routledge.

Boasson, E. L., \& Huitema, D. (2017). Climate governance entrepreneurship. Environment and Planning C: Politics and Space, 35(8), 1343-1361.
Boasson, E. L., \& Wettestad, J. (2013). EU climate policy: Industry, policy interaction and external environment. Farnham: Ashgate.

Change Partnership. (2014). Undated letter. Retrieved from http://www.changepartnership.org/wp-content/ uploads/2014/03/ECOUN-2014-EEAG-DE-FR-IT-UKresponse-draft-proposals.pdf

Bürgin, A. (2015). National binding renewable energy targets for 2020, but not for 2030 anymore: Why the European Commission developed from a supporter to a brakeman. Journal of European Public Policy, 22(5), 690-707.

Büthe, T. (2016). Historical institutionalism and institutional development in the EU: The development of supranational authority over government subsidies. In T. Rixen, L. A. Viola, \& M. Zürn (Eds.), Historical institutionalism \& international relations (pp. 37-67). Oxford: Oxford University Press.

Court of Justice of the European Union. (2000). PreussenElektra: Opinion of Advocate General Jacobs delivered on 26 October 2000. Case 379/98. Luxembourg: Court of Justice of the European Union.

Court of Justice of the European Union. (2001). PreussenElektra: Judgement of the Court. Case 379/98. Luxembourg: Court of Justice of the European Union.

Court of Justice of the European Union. (2008). Opinion of Mr. Advocate General Mengozzi delivered on 24 January 2008. Essent Netwerk Noord BV Case C206/06. Luxembourg: Court of Justice of the European Union.

Court of Justice of the European Union. (2013). Judgement of the Court Association Vent De Colere! Case C-262/12. Request for a preliminary ruling under Article 267 TFEU from the Conseil d'État (France). Luxembourg: Court of Justice of the European Union.

Court of Justice of the European Union. (2016). Judgment of the General Court of 10 May 2016-Germany v Commission (Case T-47/15) (1). Luxembourg: Court of Justice of the European Union.

Cointe, B., \& Nadaï, A. (2018). Feed-in tariffs in the European Union: Renewable energy policy, the internal electricity market and economic expertise. Cham: Palgrave Macmillan.

Community Guidelines. (2001). Community guidelines on state aid for environmental protection. Official Journal of the European Communities, (2001/C 37/03).

Community Guidelines. (2008). Community guidelines on state aid for environmental protection. Official Journal of the European Union, (2008/C 82/01).

Community Guidelines. (2014). Community guidelines on state aid for environmental protection and energy 2014-2020. Official Journal of the European Union, (2014/C 200/01).

European Commission. (2008a). The support of electricity from renewable energy sources (Commission staff working document, SEC 57). Brussels: European Commission. 
European Commission. (2008b). Proposal for a directive of the European Parliament and of the Council on the promotion of the use of energy from renewable sources (COM (2008) $30 \mathrm{final} / 19$ final, SEC 2008 57, SEC 2008 85, 23 January). Brussels: European Commission.

European Commission. (2014). Impact assessment. Accompanying the document communication from the Commission Guidelines on state aid for environmental protection and energy for 2014-2020 (Commission staff working document, SWD 139). Brussels: European Commission.

European Commission. (2016). State aid modernisation (SAM) and its implementation. European Commission. Retrieved from http://ec.europa.eu/ competition/state_aid/modernisation/index_en.html

Fitch-Roy, O., Benson, D. and Woodman, B. (2019). Policy instrument supply and demand: How the renewable electricity auction took over the world. Politics and Governance, 7(1), 81-91.

Flåm, K. (2009). EU environmental state aid policy: Wide implications, narrow participation? Environmental Policy and Governance, 19(5), 336-349.

Fligstein, N., \& McAdam, D. (2012). A theory of fields. Oxford: Oxford University Press.

Green, J. (2017). Policy entrepreneurship in climate governance: Toward a comparative approach. Environment and Planning C: Politics and Space, 35(8), 1471-1482.

Grimm, D. (2015). The democratic costs of constitutionalisation: The European case. European Law Journal, 21(4), 460-473.

Grimm, D. (2017). The constitution of European democracy. Oxford: Oxford University Press.

Jacobsson, S., \& Lauber, V. (2006). The politics and policy of energy system transformation-Explaining the German diffusion of renewable energy technology. Energy Policy, 34(3), 256-276.

Kassim, H., \& Lyons, B. (2013). The new political economy of state aid policy. Journal of Industry, Competition and Trade, 13(1), 1-21.

Kingdon, J. W. (2011). Agendas, alternatives, and public policies. Boston, MA: Little, Brown. (Original work published 1984)

Kuhn, T. (2001). Implications of the 'Preussen Elektra' judgment of the European Court of Justice on the Community Rules on state aid and the free movement of goods. Legal Issues of Economic Integration, 28(3), 361-76.
Leiren, M. D., \& Reimer, I. (2018). Historical institutionalist perspective on the shift from feed-in tariffs towards auctioning in German renewable energy policy. Energy Research \& Social Science, 43, 33-40.

Martinsen, D. S. (2015). Juridical influence on policy outputs? The political constraints of legal integration in the European Union. Comparative Political Studies, 48(12), 1622-1660.

Moravcsik, A. (1993). Preferences and power in the European Community. A liberal intergovernmentalism approach. Journal of Common Market Studies, 31(4), 473-524.

Mortensen, B. O. G. (2008) The European Court of Justice decision in Case C-206/06, Essent Netwerk Noord BV. European Energy and Environmental Law Review, 17, 389-393.

Newbery, D., Pollitt, M., Ritz, R., \& Strielkowski, W. (2017). Market design for a high-renewables European electricity system (EPRG Working Paper 1711). Cambridge: University of Cambridge Energy Policy Research Group.

Rusche, T. M. (2015). EU renewable electricity law and policy. Cambridge: Cambridge University Press.

Saurugger, S., \& Terpan, F. (2017). The Court of Justice of the European Union and the politics of law. London: Palgrave.

Schmidt, S. K. (2018). The European Court of Justice and the policy process. Oxford: Oxford University Press.

Smith, M. P. (1998). Autonomy by the rules: The European Commission and the development of state aid policy. Journal of Common Market Studies, 36(1), 55-78.

Solorio, I., \& Jörgens, H. (Eds.). (2017). A guide to EU renewable energy policy: Comparing Europeanization and domestic policy change. Cheltenham: Edvard Elgar.

Stone Sweet, A. (2010). The European Court of Justice and the judicialization of EU governance. Living Reviews in European Governance, 5(2). doi:10.12942/ Ireg-2010-2

Terpan, F., \& Saurugger, S. (2018): Assessing judicial activism of the CJEU: The case of the court's defense procurement rulings. Journal of European Integration. doi:10.1080/07036337.2018.1537268

Tews, K. (2015) Europeanization of energy and climate policy: The struggle between competing ideas of coordinating energy transitions. Journal of Environment \& Development, 24(3), 267-291.

Weiler, J. H. H. (1991). The transformation of Europe. Yale Law Journal, 100(1), 2401-2483.

\section{About the Author}

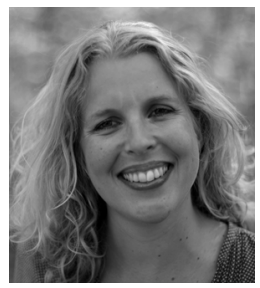

Elin Lerum Boasson is Associate Professor at the Department for Political Science, University of Oslo. She also holds a position at Cicero-Center for International Climate Research. She has published extensively on climate and energy policy and governance, exploring the role of policy entrepreneurship, business influence, political steering and Europeanization. She draws on sociological neo-institutional theories as well as historical institutionalism and public policy process theories. 


\section{Annex I: List of Interviewees}

Interviewee 1: Representative from Wind Europe, the European business association for wind energy industry. Interviewee 2: Representative from the European Commission, DG Energy.

Interviewee 3: Representative from the EFTA Surveillance Agency.

Interviewee 4: Representative from Eurelectric, the European business association for the electricity industry. Interviewee 5: Representative from the European Commission, DG Legal Service.

Interviewee 6: Representative from the European Commission, DG Competition (cabinet level).

Interviewee 7: Representative from Eurosolar, the European business association for the solar energy industry. Interviewee 8: Representative from the European Commission, DG Climate Action (cabinet level). Interviewee 9: Representative from the European Commission, DG Competition (low level).

Interviewee 10: Representative from EREF, the federation of national renewable energy associations in EU member states. 